\title{
Barriers to Inquiry-Based Instruction
}

\begin{abstract}
Inquiry-based science instruction has the potential to transform science education for both teachers and students. The implementation of inquiry-based science instruction in school curricula requires not only a shift in teachers' theoretical perspectives on science and science education, but also a change in school policy. Studies examining the impact of teachers' theoretical lenses on their teaching practices reveal that teachers who recognize the interplay of science education and society, and the idea that students build knowledge based on preexisting knowledge over time, will be more likely to see the importance of, and attempt to implement, inquiry-based instruction in their classrooms. Additionally, an analysis of policy documents reveals that: organizational change is difficult especially because those creating and implementing the policy do not fully understand or even realize the impact on teachers and students. Teachers should be fully involved in this process. Inquiry-based instruction has the potential to significantly improve the experience of science education for students and should be seriously considered by educators and policy makers.
\end{abstract}

\section{Introduction}

There has been a call for reform in science education, particularly towards implementing inquiry-based instruction, over the past two decades (Marshall \& Horton, 2011). In science education, this call seeks to help students focus on "unifying concepts and process" and to work on their critical thinking skills (Marshall \& Horton, 2011, p. 93). The call for inquiry-based instruction is crucial, as data show that our schools have not been successful in producing critical thinkers, ready to apply the knowledge gained in the classroom to the real world (Marshall \& Horton, 2011). Additionally, student interest and attitudes toward science begin to decline in middle and secondary school (Kim, 2016). It is pertinent that schools and educators give students the opportunities to engage in science and real-world scientific experiences. Doing so has the potential to create students who care about scientific issues, feel a connection to the science, technology, engineering and mathematics (STEM) field and are motivated to pursue it later on in life (Harmer \& Cates, 2007).

One possible solution to combat a rise in disengagement in science and other STEM fields, is the practice of inquiry-based science teaching (Schwab \& Brandwein, 1966). Inquiry-based instruction is a form of authentic learning that allows students to develop into critical thinkers, ready to apply their knowledge to a problem in order to arrive at an answer or a solution (Barron \& Darling-Hammond, 2008). It is a student-centered teaching method that puts the students' ideas, questions, and observations at the forefront of the learning process. Throughout the process of inquiry-based instruction, students are engaged, they collaborate with one another, and they develop a final product to demonstrate their thinking and learning (Barron \& Darling-Hammond, 2008). Traditionally, inquiry based instruction involves students developing a question, learning more about their proposed questions by performing research, developing a solution or an answer to the question and ends with an opportunity for the students to share their research and act on their solution or answer to their question (Spires, Kerkhoff \& Graham, 2016). Contrary to inquiry, a traditional classroom focuses more on rote memorization and the recitation of facts (Atkamisş, Hİ̆gde \& Özden, 2016). This notion is most commonly associated with Skinner (1954) and the theory of objectivism (Atkamisş et al., 2016). A traditional teacher is seen as the person in charge of the classroom and adopts the viewpoint that it is the teacher who allows the learning to happen. Finally, inquiry-based instruction, contrary to traditional classroom instruction, is made unique as both students and teacher equally share the responsibility for the learning taking place in the classroom (Atkamisş et al., 2016). As research demonstrates that a shift to inquiry-based instruction is beneficial for students' learning, achievement and motivation in science class (Atkamisş et al., 2016; Feldman, Chapman, Vernaza-Hernandez, Ozalp \& Alshehri, 2012; Harmer \& Cates, 2007), my paper seeks to answer the following questions: How does inquiry-based instruction represent a change in practice and theory regarding science teaching? How does policy impact this change? 


\section{Theoretical Framework}

This paper takes into account three social theoretical frameworks and how they impact the institution of the school, teacher actions and the potential for change. These theoretical frameworks are: structural functionalism, symbolic interactionism and conflict theory. Structural functionalism focuses on society "as a system in dynamic equilibrium but capable of evolving, especially in response to stresses" (Willis et al., 2007, p. 440). This paper represents society as comprised of teachers, students, administrators, policy makers, schools, parents, etc. All of these bodies need to work together to make change in schools, policy, and teaching practice. Additionally, each of these groups impact one another. Secondly, symbolic interactionism focuses on social interactions and states that these interactions "underpin the process of learning who we are and the symbolic meaning of things" (Willis et al., 2007, p. 440). This social tradition guides this paper as learning happens as a result of social interactions between teachers and students. Additionally, change can happen as a result of interactions between teachers, administrators, and policy makers. Finally, "conflict theorists assume that social structure derives from conflict between social groups" (Willis et al., 2007, p. 440). This social tradition guides this paper, as change is viewed differently by different social groups, in this case, teachers, administrators, and policy makers. Furthermore, change can be guided by different influencing factors, such as teachers' viewpoints, administration, money and educational standards. Therefore, change can bring about conflict. It is important to consider the ways in which these social theories can impact if and how teachers implement inquiry-based instruction in their science classrooms.

\section{Nature of Science and Impact on Instruction}

From the day they enter their teacher preparation programs, science teachers are fed information about science and science teaching that ultimately impacts the ways in which they teach science. Through their time in school and as a practicing teacher, teachers develop differing views and beliefs on scientific theories, scientific process and progression and the change of scientific knowledge (Brickhouse, 1990). Ultimately, "beliefs directly related to educational processes" as well as the factors listed above, influence the ways teachers perceive of science education and how they teach the content. (Brickhouse, 1990; Roehrig \& Luft, 2004, p. 4). Furthermore, in her study, Brickhouse (1990) distinguished three areas where teachers differed in beliefs and described how these differences impacted their practice. The first area of difference is that of teachers' beliefs and views of scientific theories. One teacher in the study believed that students should use theories as tools to solve problems. When describing her teaching philosophy the teacher stated, "you use the theory to make predictions and then...[try] to test the predictions. And if all of the predictions that you can make with the theory come to pass, then it's a workable theory" (Brickhouse, 1990, p. 55). The other teacher believed that students learn theories through experimentation. Therefore, this teacher assessed students on memorization (Brickhouse, 1990). A teacher who sees theories as tools to solve problems might be more inclined to use inquiry-based instruction than a teacher who believes that students should be memorizing the "truths" of science.

The second area where teachers differ in their views and beliefs is in that of scientific processes. Brickhouse (1990) found that teachers view scientific processes as inductive, and that students should be following exact procedures to discover the truth. Secondly, she found that scientific processes can be viewed as following the scientific method step-by-step. In this sense, teachers believe that both teacher and students should rely on the textbook for teaching and learning because students need structure to "train them to solve problems" (Brickhouse, 1990, p. 57). Finally, Brickhouse (1990) found that teachers view scientific processes as observation and experimentation as driven by theory. In this sense, students should predict what is going to happen in an experiment before actually performing it themselves, using their knowledge of theory and observations. This teacher believed that "theories [are] strengthened by observations" (Brickhouse, 1990, p. 57). A teacher who views scientific processes as observations and experimentation driven by theory would be most inclined to use inquiry-based instruction in their classroom.

The third area where teachers differ in their views and beliefs is that of the progression and change of scientific knowledge (Brickhouse, 1990). Brickhouse (1990) found that teachers believe that science progresses because of facts accumulating and because they acquire new interpretations for old observations rather than from 
"changes in theory" (Brickhouse, 1990, p. 57). Therefore, students learn by gathering bits of information at a time. Secondly, Brickhouse (1990) found that teachers believe that science progresses as people come up with new interpretations for old observations. Therefore, the teacher who encourages their students to continuously modify their thoughts and opinions resulting from new interpretations of what they already know, would be most inclined to use inquiry-based instruction in their classroom.

\section{Shift in Perspectives of Science Teaching}

In order for teachers to change the ways in which they are teaching science, they must also shift their perspectives, or theoretical lenses, regarding science instruction and how they believe it should be done. Firstly, it is important that teachers understand that science education is a social activity bound within institutions (Lemke, 2001; Magnusson, Palinscar \& Templin, 2006). Science is a product of "thought and activity patterned in particular ways through the social processes of interaction within a community drawn together by shared values and beliefs" (Magnusson et al., 2006, p. 131). Both teachers and students need to understand how science is intricately tied with the social world, and that this connection extends far beyond the classroom. Science should be understood as "very much a part of and not apart from the dominant cultural and political issues of the day" (Lemke, 2001, p. 298). In this sense, science classrooms should be seen as classroom communities, where knowledge is generated, discussed, debated and refined (Lemke, 2001; Woods-McConney, Wosnitza \& Sturrock, 2016). Additionally, science classrooms should include not only the learning of specific science concepts, but should also take into account different ideas (Lemke, 2001). "Ideas are exciting and they enable us to have new and richer experiences in the future" (Lemke, 2001, p.309). This notion is central to an inquiry-based classroom, as students' ideas and curiosity are central to the learning process ('Inquiry based learning', 2013). Both teachers and students are influenced by the social world which impacts how they view, teach and learn science.

As described by Gholson and Barker (1985), the shift in the perspective of science as composed within a research paradigm to research traditions, is imperative for teachers to shift their pedagogical practice. A research paradigm is something that can only exist on its own, and not at the same time as other research paradigms(Gholson \& Barker, 1985). Contrary to a research paradigm, a research tradition is something that evolves over time, takes into account other research traditions and can exist concurrently (Gholson \& Barker, 1985). Kuhn stated that any scientific work done within one paradigm has "little relevance to another" and these paradigms "do not agree on what constitutes the meaning of truth" (Gholson \& Barker, 1985, p. 755). Additionally, these paradigms are central to how scientists make sense of the world, and "the replacement of one by another is a cataclysmic event" (Gholson \& Barker, 1985, p. 755). Notably for science teaching, Kuhn denied that experimental evidence played any decisive role in bringing about scientific change. A teacher with these views would not see the importance or even possibility of using inquiry-based instruction. These beliefs were criticized a philosopher, Lakatos, who coined the term "research programs" (Gholson \& Barker, 1985, p. 757). A research program involves theories, that are linked and have the "ability to simulate the development of more complex and adequate theories" (Gholson \& Barker, 1985, p. 757). An experimental failure leads to the replacement of a research program. Furthermore, "an acceptable new theory must accommodate the successes of its predecessor and explain the data that brought the earlier theory into question" (Gholson \& Barker, 1985, p. 757). Additionally, a good theory "leads to new predictions that are verified experimentally" (Gholson \& Barker, 1985, p. 757). Finally, Laudan sought to further develop Lakatos' viewpoints by coining the term "research tradition" (Gholson \& Barker, 1985, p. 767). "A research tradition consists of a family of theories sharing a common ontology and methodology" and these "change as the research tradition evolves" (Gholson $\&$ Barker, 1985, p. 761). Unlike Lakatos, Laudan stressed the importance of conceptual factors when thinking about a theory's legitimacy. A teacher who views scientific change and progress as associated with research traditions, would be more inclined to adopt inquiry-based instruction in their classroom, as they consider all aspects of science, including ontology, methodology and conceptual factors. Additionally, this teacher will likely stress that research traditions can change and evolve with new evidence or interpretations of scientific theories. 


\subsection{Methodological and Dialectical Models of Science}

If science teaching is going to shift towards inquiry-based pedagogies, "then contemporary views of the nature of science suggest that we need to think in fundamentally different ways about instruction" (Magnusson et al., 2006, p. 131). The more traditional way of thinking about science instruction is viewed as the methodological model. This viewpoint states that the scientist happens upon a discovery simply by "being in the right place at the right time" (Magnusson et al., 2006, p. 132). In the methodological view of science, method is the key factor in determining if the scientist discovered the "right" facts at the right time, and in this way, scientific knowledge is constructed. However, a more contemporary view of science thinking and teaching is termed the "dialectical model" (Magnusson et al., 2006). This model includes scientists, nature, and another group of scientists "that debates with the first according to the features of scientific dialects" (Magnusson et al., 2006, p. 133). A scientific theory's rationality is based on nature, the community's agreement and the quality of their argument of the theory. The scientific community enables the production and validation of the scientific theory. This community is known as the workbench community (Magnusson et al., 2006). "Workbench science communities typically involve a relatively small group of individuals who work closely with others in ongoing collaboration to solve problems of immediate and joint concern" (Magnusson et al., 2006, p.135). This workbench community is critical in relating science to both community and culture, as science is a product of the culture and community in which it is derived. As inquiry-based instruction stresses the importance of students working together as a community of scientists in the classroom to debate and arrive at a shared understanding of knowledge, it is crucial that the teacher views science knowledge and teaching as adhering to the dialectical model (Feldman et al., 2012).

Finally, in order for teachers to be inclined to implement inquiry-based instruction in their classrooms, they must take part in conceptual change perspectives (Treagust \& Duit, 2008). Treagust and Duit (2008) state that "teachers hold conceptions of science concepts that are not in accordance with the science view...[and] hold limited views of the teaching and learning process and of the nature of science" (Treagust \& Duit, 2008, p. 298). Therefore, in order for teachers to meet the needs of all of their students, and address the misconceptions that their students hold upon entering science class, a teacher needs to be committed to undergoing their own conceptual change, in order to promote conceptual change within the student as well. Learning and teaching science, especially from an inquiry-based pedagogy, requires many changes in perspectives both in how the students see the construction of science knowledge and in how the teacher believes that this knowledge can be constructed. Doing so will provide more opportunity for a teacher to see the importance of inquiry-based instruction and implement this pedagogy in their classroom. This notion of conceptual change, however, is criticized by those who view science as a sociocultural process (Lemke, 2001). Therefore, it is important to consider both students' and teachers' understandings of science and how these can be changed by inquiry-based teaching, but also to be aware of the social, cultural and political conditions that may affect these understandings and make change harder to achieve. As educators "we should give students [and teachers] opportunities to change their minds, but we should not do so unaware that we are thereby inviting them to join a particular subculture and its system of beliefs and values" (Lemke, 2001, p. 312).

\section{Organizational Change and Reform}

The implementation of inquiry-based instruction in science classrooms not only depends on a shift in teachers' theoretical views of science teaching, but it also requires organizational change and reform. The institutions, standards and educational policies and teachers should all support this shift.

Historically, organizational change is thought of as happening from a "top-down" approach (Ball, 1987). Change is made to reflect the needs and wants of administrators, but ignores the other people who are part of the "system" or institution. This type of change contains " a view of the organization looking down from the position of those 'in control.' They are inherently biased and distorted by this partiality" (Ball, 1987, p. 5). This top-down approach to organizational change is extremely limiting as it prevents opportunities for other forms of organization (Ball, 1987). According to Ball (1987) these theories of change "marginalize empirical studies of

school practice and dismiss the "folk knowledge" of teachers as irrelevant" (p. 5). Schools cannot be thought of as similar to large corporations or factories, but with a top-down approach to change, they are regarded just as 
so. In order for change to take place within schools, the top-down theory of organization needs to be completely rejected, for an alternative, more inclusive process of change.

There are three perspectives that can influence organizational change (Datnow \& Park, 2012). The first perspective, the technical-rational, represents a top-down approach to policy reform (Datnow \& Park, 2012). This perspective "attends to the administrative and procedural aspects of policy implementation while ignoring or downplaying the influence of context" (Datnow \& Park, 2012, p. 348). As a result, the policy being implemented using this approach may not produce the intended outcomes, as the context in which the policy will be enacted is being ignored. The second perspective, mutual adaptation, is a bottom-up approach to policy reform (Datnow \& Park, 2012). This approach stresses the importance of context in order to understand the outcome of a policy, and therefore would be more likely to result in the desired outcomes (Datnow \& Park, 2012). The third perspective, sense making/ co-construction involves building upon existing ideas that exist in the context and "elaborating on the interconnections between actors and explaining just exactly how context has shaped policy implementation" (Datnow \& Park, 2012, p. 350). Therefore, when considering organizational change and reform that would lead to the implementation of inquiry-based instruction it is important that this is done from a sense making/ co-construction model, as this process treats policy creation and implementation as one process, and will be more likely to consider the context, and the variables within the context that would affect implementation.

These various views of organizational change demonstrate that change within an institution can only occur with change at the political level but also from change within the organization itself. In order to change teachers' pedagogies, change needs to occur at many different levels. This shift can be difficult to achieve as it can create conflict between all of the people and organizations involved.

In their article, Keys and Bryan (2000) explicitly stated that, when considering inquiry implementation, teachers' voices are essential in the process of curriculum design and reform. They state: "teacher knowledge, actions, and meanings for inquiry-based science [should be] at the center of the reform process" (Keys \& Bryan, 2001, p. 631). Relatedly, they stress the importance of a transformational model of teaching reform (Keys \& Bryan, 2001). This model recognizes the importance of the teacher's beliefs, understands that they will face tensions throughout the reform process, but encourages them to engage in reflection and to create "interactive environments for fostering conceptual connections" (Keys \& Bryan, 2001, p. 634).

Although it is important to engage teachers' voices in educational policy and practice reform, it is also crucial to recognize that it is difficult to involve teachers as they do not hold authority in policy makers' eyes (Thomas, 2005).In her article, Thomas (2005) discusses three reports constructed to implement educational reform, all of which view teachers as not being necessary for change. These reports, the Wiltshire Report, Teachers for the 21st Century and The White Paper, discuss teachers as being agents of change, but contradict this viewpoint when explaining that teachers do not have the expertise or knowledge of policy to actually be involved in change (Thomas, 2005). In these reports, teachers are positioned as passive participants who need to raise their professional quality, and who should be regulated through standards (Thomas, 2005). While, in theory, teachers are discussed as being necessary for change, in practice this is not happening. If we are to shift towards more inquiry-based instruction, teachers' voices need to be heard and teachers should be active participants in policy creation and implementation.

Finally, it is important to examine policy's direct impact on practice (McNeil \& Coppola, 2006). Policy is acted out differently in the classroom than on paper. McNeil and Copppola (2006) state that "only through research in classrooms, schools and communities that is fine grained enough to track significant and compelling narratives, sensitive enough to explore the definitional contours of the policy, and persistent enough to pursue discrepant explanations can we truly understand how policies affect the lives and learning of the children they are intended to help" (McNeil \& Coppola, 2006, p. 681). Therefore, it is important to examine a policy and its impact using multiple methodologies while also focusing on the impact on children, in order to achieve an understanding of how this policy could potentially impact schools and classrooms (McNeil \& Coppola, 2006).

\subsection{Case Studies: Change in Action}

In order to understand the large task of implementing inquiry-based instruction in a school, it is important to look at specific case studies which demonstrate how the politics of the school could impact the potential for 
change.

Ball (1987) describes one case at a school where changes were made in the organization of students. This change also had large impacts on teaching practices, similar to inquiry-based instruction. The idea for change originated with the headteacher, and while he played a critical role throughout the whole process, it also involved the input of others, as the change would affect everyone in the end. The headteacher involved himself in the micro-politics of the school, before beginning this process of change, by gathering support of administrators and teachers who were in favour of this reform. While not everyone agreed with this change, it was done in a democratic way that included the opinions of all, and where each step built upon the other, eventually making this reform possible (Ball, 1987). This type of change represents a sense-making and co-construction model of change.

A second study comes from Schoenfeld and Kilpatrick (2013) and looks at the challenges associated with the implementation of inquiry-based instruction in mathematics in the United States. They stress that it is crucial to keep in mind that the US education system represents a variety of systems and contexts, all of which would impact the uptake of inquiry-based instruction (Schoenfeld \& Kilpatrick, 2013). As different states across the U.S. have different systems for education and teacher education, each state should be considered separately, and within each state, each school operates differently, impacting the potential and strategies for change (Schoenfeld \& Kilpatrick, 2013). The federal government also plays a large role in the incentives that lead schools and states to uptake certain systems, which also impacts if they can implement inquiry into their teaching. This is just one instance that represents that, no matter how many people may be on board with change, there are larger factors that ultimately come to play and influence the potential for change.

\section{Conclusion}

The call for a shift towards inquiry-based instruction is one that should be taken seriously by all educators, administrators and policy makers. Implementing this pedagogy has the potential to change science education for many students. While it is beneficial, implementing such a pedagogy requires change not only in institutions, but also from teachers. The implementation of inquiry-based instruction requires a shift in theory regarding teaching and how scientific knowledge is constructed. This change in theory, in addition to examining the best ways in which to change school policy, have the potential to lead to more teachers using inquiry-based instruction. It is crucial, however, to include teachers in every aspect of this change and implementation, but this involvement may be difficult to achieve. 


\section{References}

Atkamisş, H., Hİ̆gde, E. \& Özden, B. (2016). Effects of the inquiry-based learning method on students' achievement, science process skills and attitudes towards science: A meta-analysis science. Journal of Turkish Science Education (TUSED), 13(4).

Ball, S. J. (1987). The micro-politics of the school: Towards a theory of school organization. New York, NY: Routledge.

Barron, B. \& Darling-Hammond, L. (2008). Teaching for meaningful learning: A review of research on inquirybased and cooperative learning. Powerful Learning: What we know about teaching for understanding, 1170. Retrieved from https://files.eric.ed.gov/fulltext/ED539399.pdf

Brickhouse, N. W. (1990). Teachers' beliefs about the nature of science and their relationship to classroom practice. Journal of Teacher Education, 41(3), 53-62.

Datnow, A. \& Park, V. (2012). Conceptualizing policy implementation: Large-scale reform in an era of complexity. Handbook of Education Policy Research. Routledge.

Feldman, A., Chapman, A., Vernaza-Hernandez, V., Ozalp, D. \& Alshehri, F. (2012). Inquiry-based science education as multiple outcome interdisciplinary reearch and learning (moirl). Science Education International, 23(4), 328-337.

Gholson, B. \& Barker, P. (1985). Kuhn, lakatos and laudan: Applications in the history of physics and psychology. American Psychologist, 40(7), 755-769.

Harmer, A. \& Cates, W. (2007). Designing for learning engagement in middle school science. Computers in the Schools, 24(1-2), 105-124.

Inquiry based learning. (2013). Pamphlet. Ontario Ministry of Education.

Keys, C. W. \& Bryan, L. A. (2001). Co-constructing inquiry-based science with teachers: Essential research for lasting reform. Journal of Research in Science Teaching: The Official Journal of the National Association for Research in Science Teaching, 38(6), 631-645.

Kim, H. (2016). Inquiry-based science and technology enrichment program for middle school-aged females. Journal of Science Education and Technology, 25(2), 174-186. doi:10.1007/s10956-015-9584-2

Lemke, J. L. (2001). Articulating communities: Sociocultural perspectives on science education. Journal of Research in Science Teaching, 38(3), 296-316.

Magnusson, S. J., Palinscar, A. S. \& Templin, M. (2006). Community, culture and conversation in inquiry based science instruction. In Scientific inquiry and nature of science (pp. 131-155). Springer.

Marshall, J. C. \& Horton, R. M. (2011). The relationship of teacher-facilitated, inquiry-based instruction to student higher-order thinking. School Science and Mathematics, 111(3), 93-101.

McNeil, L. \& Coppola, E. M. (2006). Official and unofficial stories: Getting at the impact of policy on educational practice. Handbook of Complementary Methods in Education Research, 681-700.

Roehrig, G. \& Luft, J. (2004). Constraints experienced by beginning secondary science teachers in implementing scientific inquiry lessons. research report. International Journal of Science Education, 26(1), 3-24.

Schoenfeld, A. H. \& Kilpatrick, J. (2013). A us perspective on the implementation of inquiry-based learning in mathematics. ZDM: Mathematics Education, 45(6), 901-909.

Schwab, J. J. \& Brandwein, P. F. (1966). The teaching of science as enquiry. In J. J. Schwab \& P. F. Brandwein (Eds.), The teaching of science (pp. 3-103). Cambridge, MA: Harvard University Press.

Spires, H. A., Kerkhoff, S. N. \& Graham, A. C. (2016). Disciplinary literacy and inquiry: Teaching for deeper content learning. Journal of Adolescent Adult Literacy, 60(2), 151-161.

Thomas, S. (2005). Taking teachers out of the equation: Constructions of teachers in education policy documents over a ten-year period. The Australian Educational Researcher, 32(3), 45-62.

Treagust, D. F. \& Duit, R. (2008). Conceptual change: A discussion of theoretical, methodological and practical challenges for science education. Cultural Studies of Science Education, 3(2), 297-328.

Willis, K., Daly, J., Kealy, M., Small, R., Koutroulis, G., Green, J., ... Thomas, S. (2007). The essential role of social theory in qualitative public health research. Australian and New Zealand Journal of Public Health, 31(5), 438-443.

Woods-McConney, A., Wosnitza, M. \& Sturrock, K. (2016). Inquiry and groups: Student interactions in cooperative inquiry-based science. International Journal of Science Education, 38(5), 842-860. 